\title{
2. Pasifika media in the digital era
}

\section{AB.SIRA CI}

The proportion of people who identified as Pacific Islanders in New Zealand grew by 14.7 percent to 265,974 in the 2005 Census. Overall, Pacific people now comprise almost 7 percent of the total New Zealand population. As the Pacific communities have grown, so have the Pasifika media developed and grown. Today, most of the Pacific Islands community has become well served by radio, newspapers, online media and, to a lesser extent, television - but not well served by mainstream media. Almost all of the media services are owned/and or operated by Pacific Islands businesses or organisations based either in New Zealand or in the Islands. This commentary outlines the state of Pasifika media in New Zealand and the challenges ahead for telling Pacific stories in the digital era.

\section{JOHN UTANGA}

Chairman, Pacific Islands Media Association (PIMA)

$\mathrm{P}$

RELIMINARY results from the 2005 Census show significant growth in the ethnic makeup of the New Zealand population in the last four years. The Asian ethnic group had the largest growth since 2001, up 48.9 percent to reach 354,552 . This ethnic group now represents 9.2 percent of those who stated their ethnicity. The Maori population grew by 7.4 percent to 565,329 since the last census in 2001 and the proportion of people who identified as Pacific Islander went up 14.7 percent to 265,974 . Overall, Pacific people comprised 6.6 percent of the total New Zealand population on census night 2005.

In terms of the individual breakdown of the size of the various Pacific communities, that data is not yet available but it would be safe to assume that there would not be too much change from the data collected in 2001. At that time, the demographics breakdown was as follows:

- Samoan people made up the single largest Pacific ethnic group, comprising 115,000 or 50 percent of NZ's Pacific population.

- This was followed by Cook Island Maori (52,600 or 23 percent).

- Tongan $(40,700$ or 18 percent) 
- $\quad$ Niuean $(20,100$ or 9 percent $)$

- Fijian (7000 or 3 percent)

- Tokelauan (6,200 or 3 percent) and Tuvaluan, (1960 or just under 1 percent)

- The Fijian population decreased over the same period (down 8 percent or 700 ).

- At the time of the 2001 Census, there were 231,800 Pacific people in New Zealand.

Significantly, about 70 percent of the Pacific population at the 2001 Census was under the age of 30 .

\section{An overview of Pasifika media in New Zealand}

Ever since Pacific Islands people began arriving in New Zealand in the middle of the 20th century, the desire for news and information from the homelands has been an important part of maintaining their identity in New Zealand society. Being such an integral part of Pacific communities, churches provided the earliest means by which news was disseminated and this was followed later by more traditional media such as radio broadcasts and newspapers when printing costs came down and community radio began to emerge. As the communities grew, so did the number and type of media services. Over time, with the growing number of New Zealand-born Pacific people, the audience began to change as well and Pacific media has largely managed to move with the times albeit, not without some casualties. Today, overall, most of the Pacific Islands community in New Zealand is well served by radio, newspapers, online media and, to a lesser extent, television. And almost all of those services are owned and/or operated by Pacific Islands businesses or organisations based either in New Zealand or in the islands.

\section{Radio}

In New Zealand today, the section of Pasifika media that appears to be the best served is radio. But this has come about relatively recently and with a massive injection of funds from the government. Those funds are directly responsible for NiuFM, a radio station based in Auckland and managed under the guidance of the National Pacific Radio Trust (NPRT). It has a national footprint and was set up by the government which provided startup costs and, to date, operational funding. While the station has had its teething problems in recent years it continues to provide news, music and entertainment (mostly in English) as well as language-specific community 
broadcasting in the evenings. It employs a large pool of Pacific Islands announcers, field reporters and administrative and sales staff. At the end of 2006, NiuFM took over the management of long-running Auckland community radio station radio 531pi, swelling staff numbers, particularly those responsible for community programming. Radio 531pi itself had been a pioneer broadcaster within the Pacific community having run for almost 15 years under the management of the Auckland Pacific Islands Community Radio Trust (APICRT). It was partly funded through New Zealand On Air and it served the Auckland region primarily but it could be heard wider afield. The mainstay of its programming was its nightly community broadcast in the various languages, a model now adapted by NiuFM.

While Radio 531pi has merged with NiuFM, it still operates as an Auckland community station. Other Pacific Islands stations or programmes have also emerged over the past few years. Having such a large Samoan community in New Zealand has led to the establishment of Radio Samoa in Auckland and Samoa Capital Radio (SCR) in Wellington. Radio Samoa for the last seven years has grown steadily and broadcasts predominantly in Samoan with English commercials and music from time to time. SCR shares transmission facilities with Wellington Access Radio but is an independent operation. Access radio throughout New Zealand provides plenty of opportunity for Pacific Islands programming particularly in the smaller centres and at last count about 22 percent of access radio hours were dedicated to programming for Pacific Islands Communities. ${ }^{1}$ Finally, Radio New Zealand International deserves a mention here. Funded indirectly by government, the service was set up to provide news and coverage of the Pacific Islands for the region. Based in Wellington, it employs both Pacific and non-Pacific staff to produce comprehensive hourly bulletins.

\section{Print}

Newspapers continue to serve the Pacific communities well, although there was a short period of retrenchment for some titles while others just stopped publishing. (the long-running Samoana newspaper stopped publishing in 2006 for a revamp but, to date, it has yet to appear on store shelves). Nearly all the Pacific Islands newspapers publish in their own languages and carry only minimal English language content. There is no pan-Pacific English language newspaper in New Zealand although there have been attempts to produce them. An attempt at one failed miserably some years ago, that 
publication was produced by the Lali Media group which owns the Taimi $O$ Tonga among other titles. At the time publisher Kalafi Moala explained that readership was lacking. In fact, an English-language version of his flagship Taimi newspaper had to be abandoned for lack of sales. Today the Taimi is published only in the Tongan language and distributed throughout New Zealand, Tonga, Australia and the United States. While the Taimi continues to serve a loyal Tongan readership and go from strength to strength, it has also spun-off other newspapers. Staff from that publication have gone on to set up their own publications. Former Taimi editor Filo Akau'ola established Talaki in 2005 and former journalist Kite Tualau'kau established Tonga Taina in early 2006. The Tongan community is also served by the newspaper Kele'a which has been its longest-running publication. For economic and political reasons, all four titles are published out of Auckland but distributed widely.

The Samoan community has always been well served with their own publications although the Samoana, which had published for more than 20 years, has yet to resume publishing. Since the death of its founder and owner some years ago, the Samoana had been in difficulties and the proposed revamp of the paper was a response to this. The Samoa Post has operated out of South Auckland for the best part of a decade and continues to hold its readership while the Samoa Times, closely aligned with the owners of Samoa Radio in Auckland, is a recent addition to the Auckland scene. Like their Tongan counterparts, these two newspapers are published in New Zealand and distribute locally and overseas. In the last year or so, the Apia-based Samoa Observer has begun reprinting and distribution in New Zealand. Unlike the other publications, Samoa Observer is a bilingual newspaper carrying news in both English and Samoan. One other bilingual title, Samoa International, folded in 2006. It was initially part of the Lali Media Group but was bought by the then editor who ran it independently until its demise.

For its size (the second largest of the Pacific Islands communities), the Cook Islands community is sadly lacking in a community newspaper for itself although some publishers have attempted to produce one over the years. In the 1980s the Cook Islands Times emerged briefly and in the mid 1990s the Cook Islands Press was published out of Auckland for only a few months. Following its demise the Cook Islands Star emerged and reached some measure of success before its owner sold it to the Lali Media Group. Lali ran the paper for a year before it decided to close it down for lack of 
readership. All the Cook Islands newspapers were bilingual. The smaller Pacific communities have had their share of the newspaper market; the Fiji Observer operates with mixed success to cater for the small numbers of indigenous Fijians living in New Zealand and the Niue Star operates out of Auckland in much the same way - sometimes they publish, sometimes they do not and both papers are bilingual. It is interesting to note that the much larger Indo-Fijian community is well served with its own newspapers and one of its widest read is the Indian Tribune, which is part of Lali Media Group.

Magazines specifically for Pacific people in New Zealand have not been as prolific, although the community has been well served over the years by publications from off-shore such as Pacific Islands Monthly (in its time), Islands Business and Matangi Tonga. In New Zealand, the Maori magazine Mana often carried stories about Pacific Islands people. In 2004 however, Spasifik magazine began publishing. It has been a welcome addition to the media landscape with its focus on the achievement of Pacific people as well as local and regional issues and it is a publication which is targeted at the growing brown and urban middle class. It is published in English, is distributed locally and overseas and is produced to such a high quality that it is certainly not out of place in mainstream book stores. A recent addition to the magazine scene is another Tongan publication called Moana. It contains Tongan news and reviews and is published bimonthly. There have been other smaller niche publications but all too often they appear sporadically and some have just disappeared.

\section{Television}

Until recently television has not attracted Pacific communities in large numbers to participate in providing a television service as such, probably because of the prohibitive costs of such an enterprise. This is not to say that there has not been a television presence - there has and it's been in the form of the long-running programme Tagata Pasifika at TVNZ. It is celebrating 20 years on air this year and its half-hour of weekly programming on a national network has come thanks to government funding via New Zealand On Air. Tagata Pasifika is fully staffed by Pacific Islanders who provide a news/ magazine mix from the region and locally. Of course the programme would not have existed were it not for the commitment from the broadcaster. TVNZ has to be commended. Tagata Pasifika is not the only programme funded by the government, Pacific Beatstreet on TV3 also gets NZ On Air fund- 
ing. It is targeted at a youth audience, has a fixed run and will soon be into its fourth season. The programme is produced by Drum Productions owned by Tongan Stan Wolfgramm and his wife. Outside of the national networks, television production by Pacific people has been growing. This is particularly evident in Auckland where Triangle Community Television has provided a vehicle for communities to produce their own content. With relatively low entry costs and the falling cost of production due to advances in digital technology, this opportunity has been grasped by a handful of producers. Injoy Productions makes TNews, a news show for the Tongan community, which would not disgrace a national network, while another Tongan group has a regular religious programme. The Samoan community have Pasefika Nius, a mix of entertainment and news and magazine stories from New Zealand and Samoa. Regular replays of Fiji One News from Suva also feature in Indo-Fijian programmes on Triangle.

\section{Online}

The amount of online media content for the Pacific communities in New Zealand is growing rapidly, but not as fast as it has been overseas. Pacific communities in the United States for example have been well served for many years by community/news operations possibly because of a better understanding of and access to online technology. The popular Polynesian Café website $^{2}$ is an example. Today, however, Pacific Islands publishers in New Zealand are beginning to see the benefits of an online presence and have responded strongly. The Samoa Times ${ }^{3}$ is a good example as is NiuFM. ${ }^{4}$ New Zealand-based Event Polynesia ${ }^{5}$ has also grown into a strong online provider of news. It has its own reporting team and is strongly aligned with the Samoa Post. Of course larger publishers and broadcasters such as TVNZ have created strong online brands for its programmes-Tagata Pasifika makes available its story as streaming video from its website, Radio New Zealand International has both streaming content and story transcripts. In New Zealand, online content for Pacific people is really only in its infancy so there are challenging times ahead.

\section{The mainstream media}

For the purposes of this commentary the mainstream media is the rest of the non-Pacific media in New Zealand. This includes television, newspapers, radio and online media. Strictly speaking, historically the mainstream media 
has never gone out of its way to cover local and even regional Pacific Islands issues, unless that news is perceived to have had an impact on the wider local or national community. Therefore coverage was often restricted to headline grabbing events or issues - overstayers, crime, coups, conflict. Important stories about immigrant issues, achievement and human endeavour were often only covered by the Pacific Islands media. In the last decade though, there appears to have been a slight shift in the way the mainstream covers Pacific issues and perhaps this has come about because of a wider awakening or understanding about New Zealand's neighbours and the country's place in the Pacific. Certainly, events in the region over the past 20 years from military takeovers to natural disasters - and open warfare in some casesmean the Pacific is difficult to ignore.

Whatever the cause, it is clear that some mainstream organisations believe specialists are required to provide that understanding. TVNZ formed a Pacific Unit within its newsroom following the George Speight coup in May 2000. And although that unit has been reduced to just one person, reporter Barbara Dreaver (of part i-Kiribati heritage) continues to provide stories the network would never otherwise have had. On Radio New Zealand Richard Pamatatau, a Cook Islander, keeps Pacific news and issues in their main bulletin as often as he can. On The New Zealand Herald, seasoned Samoan writer Tapu Misa produces a weekly column which gives New Zealanders an insight into the issues which pre-occupy Pacific people. ${ }^{6} \mathrm{Her}$ column is perceptive and widely read. The reality is however, that only a handful of Pacific Islands reporters work in mainstream media. Those reporters are spread across newspapers and radio stations throughout the country but, to my knowledge, none work in a specialty role on Pacific issues on the major city dailies, although those same newspapers employ non-Pacific reporters to cover Pacific affairs.

\section{Language}

Understandably, the majority of independent Pacific Islands media in New Zealand publish language-specific content although English is increasingly being used in newer mediums such as in online content. In print, languagespecific newspapers have proven the most successful in the past while on radio and in community television the emphasis is very much on languagespecific programming. This is particularly the case among the Samoan and Tongan community where language literacy is relatively high. In print, many of the newspaper publications are small, family or church-run businesses 
which run a very tight operation. In many instances, editorial staff are chosen for their language proficiency rather than for any training in media. While no hard data exists on the number of Pacific Islands reporters who work on these ethnic newspapers who have a degree of formal media training, anecdotal evidence suggests that it is nothigh. Interestingly, the success of these language-specific publications to date flies in the face of statistics which show that the Pacific community is largely a youthful population with a growing number who claim English as their first language.

This is understandable given the growing number of Pacific people who are second or third generation immigrants. Perhaps it is too early to see what effect that statistic will have on Pacific Islands media but certainly online content tends to be mostly in English which is probably more an indication that younger, more technologically savvy people are accessing it. It is also telling that hourly news bulletins on the main Pacific radio network (NiuFM) are in English and are transcribed for use on the station's website. Certainly the station makes no bones about the fact that its target audience is the youth market.

\section{Journalism training}

There is a distinct lack in the number of trained Pacific Islands journalists in New Zealand. Despite the many opportunities which exist in New Zealand for formal journalism qualifications, the fact is too few Pacific people choose to go down that path. In terms of job status, it is certainly not perceived as having the kind of prestige that a career in medicine or law seems to have among Pacific people. There are other reasons of course, both cultural and economic, however, at the 2006 Pacific Islands Media Association (PIMA) conference, veteran Pacific journalist and broadcaster Sefita Hao'uli remarked that 'journalism' just had that 'too-hard' tag and that many Pacific Islands students preferred to divert their energies into other parts of the media. There is a grain of truth in that, particularly when you see the numbers of Pacific people thriving in the creative arts but not in writing. Whether you agree with Hao'uli or not, it is obvious that some serious thought needs to be given to entice Pacific people into journalism. The evidence is only anecdotal, but having been in the industry for over a decade and a half and seeing the few who have gone on to make a career out of it, it is certainly disquieting. Many of the Pacific journalists still working in the industy today came out of Manukau Polytechnic's Pacific Islands Journalism course 
which ran from the end of the 1980s until 1994. Adapted from the New Zealand Certificate in Journalism it recruited well (some students already had bachelor degrees) and gave graduates a vital leg-up into the industry. Since the demise of the course all those years ago, the number of Pacific people coming through has reduced significantly in my view. It is an issue in which we at PIMA have been grappling with since the organisation was set up in 2001. One of the first things PIMA did was to find ways in which to assist students who chose to study communications and to this end two scholarships were secured with the assistance of AUT University. We at PIMA are certainly grateful for the scholarships but understand that there is still much to be done. The irony is, this shortage in trained Pacific Islands journalists comes at a time when there is great demand for their services from the growing Pacific media and from the mainstream. NiuFM has struggled to fill its roster of journalists, print publishers are always on the lookout for that combination of good language skills and journalism training while, particularly in Auckland, larger city papers would snap up a qualified Pacific Islands reporter given the changing demographic face of the city in the years to come.

\section{Conclusion}

Pacific people have made great strides since arriving here en mass in the 1950s and the 1960s. Pacific people have reached great heights in New Zealand society and continue to punch well above their weight, particularly in the area of the country's national sport—rugby union. Four Members of Parliament are of Pacific Islands extraction as are two district court judges. At the same time however, Pacific people are over-represented in alarming social statistics, particularly in health and in law and order. Mean average incomes remain low and education achievement levels remain below the national average. Pacific people continue to migrate to New Zealand, use medical services and do business; they make up almost 7 percent of the population. Given the contribution Pacific people make to New Zealand society, the numbers in the media providing that all-important balanced or 'other' viewpoint is miniscule. This has to be a concern for the Pacific and wider community.

There was a time when the only reason a Pacific person made the news was as the protagonist in a crime story or under the torchlight of an immigration officer. We say to ourselves, thankfully those days are over. But 


\section{JOURNALISM DOWNUNDER}

the reality is Pacific people are always going to make the news, whatever the circumstance is. We need to be able to educate the public about our values and hopes and desires so that New Zealand, as a society, gets a better appreciation of its neighbours. As a community, Pacific people must make sure their side of the story is told in the digital era or face further marginalisation in New Zealand. What better way is there than to tell our stories and provide our side of the debate?

\section{Notes}

1. www.nzonair.govt.nz/pacific_island_radio.php

2. www.polycafe.com

3. www.samoatimes.co.nz

4. www.niufm.com

5. www.eventpolynesia.com

6. www.nzherald.co.nz/author/index.cfm?a_id=11

John Utanga is a founder and current chairman of the Auckland-based Pacific Islands Media Association (PIMA) and a prominent television journalist with TVNZ's Tagata Pasifika magazine programme. An ealier version of this article was presented as a paper at the Second Joint Journalism Education (JEA)/Journalism Education Association of New Zealand (JEANZ) conference, Auckland, December 4-7.

john.utanga@tvnz.co.nz 
Copyright of Pacific Journalism Review is the property of Auckland University of Technology and its content may not be copied or emailed to multiple sites or posted to a listserv without the copyright holder's express written permission. However, users may print, download, or email articles for individual use. http://www.aut.ac.nz/depts/commstud/journ/pjrsubs.shtml 